\title{
Reconfiguring the culture of kinship: poor people's tactics during South Africa's transition from apartheid
}

\author{
Andrew D. Spiegel
}

\section{Introduction}

Apartheid created tight systemic control of urbanward migration, obliging many black South Africans to maintain themselves and their dependants through oscillating labour migration that effectively constructed a single social field of the country's cities and the countryside. Resistance in the 1970s and 1980s to urban-influx controls, particularly by women (Cole 1987; Ramphele 1993; Wells 1993), helped bring an end to the system. Yet many people have continued, well after the end of apartheid, to be locked into oscillating migrancy - it has persisted as a practice for managing urban-rural livelihoods rather than, as previously, a state-determined system of labour and population control (Mabin 1990; Posel 2004; Casale and Posel 2006; White 2010; 2013). Despite trends towards permanent urban settlement, limits on (and of) the new state's service delivery systems that have generated intense resistance in recent years (Robins 2014) and limits on the state's social support structures have converged with a cultural sedimentation of people's experience of dependence on migrancy for social support.

Strategies for spreading risk have included the maintenance of social support networks stretching across towns, cities and countryside. Many people still today, two and a half decades after the fall of apartheid, reproduce the structures of migrancy through interlinking their resource bases in diverse towns and remote labour-supplying corners of the country where older relatives care for children especially now in a context of AIDS orphans, some of whom are left to care for themselves (Henderson 2011) - and where many younger working people have tended to anticipate eventually retiring. Those who intend to do so have consequently tried to create networks of reciprocity extending through various urban areas where they have attempted to generate incomes, as well as across the urban-rural divides that separate those places from people's remote rural homes (Spiegel et al. 1996b; Russell 2003; Seekings 2008).

This article discusses how culturally salient kinship principles have been used to give meaning to many of the relationships constituting these networks. It also considers how those principles have been transformed each time they are drawn upon to give meaning to new social relationships. In particular, it focuses on how ideas about clanship and clan names have been drawn upon and reconstructed.

\footnotetext{
Andrew D. Spiegel is Emeritus Associate Professor in Anthropology and holds an appointment as Senior Scholar at the University of Cape Town. Over the past forty years, he has published on a wide range of Southern African anthropological concerns, mainly relating to the local consequences of the region's political-economic dynamics. Email: mugsy.spiegel@uct.ac.za
}

(C) International African Institute 2018 
Some earlier structural-functionalist analyses addressed the pragmatic use of kinship and kin terminology. Among other reasons, they did so in order to research people's conflation of historical and genealogical memory (Cunnison 1957 ; 1959) or to reflect how, in a social context where age sets were the basis of residential contiguity and sociality, one had to succeed to and take on the deceased's position and social persona when one's immediate antecedent passed away (Wilson 1951). However, since most of that work was enmeshed in trying to make structural-functional sense of kinship's role in underpinning assumedly static or very slowly evolving social structures, it has tended to be overlooked in recent years.

A consequence is that, while there has been a subsequent body of work on the pragmatics of kinship's malleability, those contributing to it have tended not to refer to the earlier work. This is despite somewhat more recent work that has also drawn attention to the fluidity of everyday notions about who constitutes and is recognized as kin. The focus of that later work has thereby revealed the limits of understanding kinship simply as a structure in itself or one that functions to sustain and reinforce the structural principles underpinning a social organization. It has done that by adding a processual dimension to analyses of kinship and of what Carsten (1995) called relatedness.

The more recent work has largely been based on two broad empirical concerns: an interest in understanding how ideas about constituting kin are affected by new reproductive technologies (for example, Strathern 1992a; 1992b; Shaw 2017); and a reconsideration of what 'substance(s)' people treat as the signifier of relatedness, and whence that substance derives. Is it 'blood' through procreation or gestation, or bodily substances (including 'blood') created by ingestion and commensality and where forms of material reciprocity are central (see, for example, Carsten 1995; Feldman-Savelsberg 1995; Weismantel 1995)? The second concern represents a response to Schneider's (1984) critique of those kinship studies that argued for the abandonment of the concept of kinship in cross-cultural study, precisely because relatedness was constructed, in some societies, on principles other than those associated with procreation. It thus seemed merely to recapitulate earlier New Guinea work on 'nurture kinship' (Watson 1964; Strathern 1973; cf. Holy 1996: 10), which documented how common food intake and commensality overrode the biology of procreation in the ways people defined kin. Yet it went further by endeavouring to relate food intake to other material and social reciprocities (cf. Stack 1974; Weismantel 1995; Murray Li 1998; Schrauwers 1999), and, in Carsten's (1995) case, to the meaning of the house as a locus of food preparation, distribution and consumption.

Carsten's focus on the structure of the links between house, food and social relationships of relatedness among Malays in Pulau Langkawi has proved important for two reasons. It evokes Bloch's (1971) point that, while kinship is indeed malleable, people understand their relatedness not only contingently (Stack 1974; Weismantel 1995; Launay 2006) but through sets of ideas that are sedimented into consciousness through iterative practice that may yet be strategic (Comaroff and Comaroff 1981). Carsten has also demonstrated that the particularities of such sets of ideas are not universal, although the idea of making sense of relatedness is; to understand particular people's constructions of kinship, one must understand the particularities of their experience and culture (cf. Schrauwers 1999). My own argument builds on that insight. 
I report on how processes of kinship construction occurred in 1992-93, between the formal collapse of apartheid and the creation of a new democratic state, among a small cohort of poor residents in what was then the Makhaza shanty area in Khayelitsha, a sprawling African housing complex some 35 kilometres from Cape Town's central business district. ${ }^{1}$ I provide evidence of how people reconstituted ideas about relatedness to form or reinforce their relationships in and around one of the then serviced-site shack areas that, at the time, constituted most of Khayelitsha's housing and provided abodes for more than half of its then approximately 400,000 residents. $^{2}$ I examine the significance of kinship for the experience of migration and in the context of domestic consolidation processes as people tried to build what they perceived as secure households ${ }^{3}$ for themselves and for those they recognized as their dependants.

One aim of the article, then, is to examine how, especially during a crucial transition period in South Africa's transformation, people used the culture of kinship to give social salience to reciprocal and other relationships that they established in their struggles to survive the vagaries of living on the margins of urban industrial life. I examine how an overlay of kinship was placed on at least some relationships that comprised people's social networks, and how an existing culturally defined structure was imposed on contingency-based relationships, and reconstituted in the process. My interest is in discussing people's use of their own notions of kinship to cement relationships in ways that, in their understanding of society, merely contingent material reciprocities were unable to do. I also focus on those practices during what was a particularly salient moment of transition in South Africa's and Cape Town's history; doing so allows us to see how previous - and then existing - sets of cognitive and affective relations enabled people's material practices of making homes and relationships in precarious yet changing circumstances.

I draw on Bloch (1971) to show that kinship constitutes a cultural resource; an array of ideas about normative roles, to be drawn upon yet always contested as they are called into service; ideas from which people derive meaning (and which they contest and refine) just as they define for themselves, and in terms they understand, their relationships with neighbours and others who help them, and whom they help in turn - albeit sometimes contingently and sometimes over quite short time periods. ${ }^{4}$ I show how, in dealing with migrancy and everyday domestic

\footnotetext{
${ }^{1}$ Apartheid legislation for separate residential areas for each 'population group' (race) has been repealed. But the legacy has persisted with areas such as Khayelitsha still located on the city's margins and occupied almost exclusively by black Africans, many of them perilously poor, although there are now middle-class residents in Khayelitsha, which also boasts shopping centres, hospitals and schools.

${ }^{2}$ Estimates put the population now at more than twice that number.

${ }^{3}$ Such households are emically constituted as aggregations of individuals sharing a common interest in ensuring their mutual future security using a shared set of resources and potentials. Commonly (although not necessarily) the individuals are linked through consanguineal and affinal ties and they are often found in diverse parts of the subcontinent, as are their shared resources. They are thus not necessarily co-resident, and their material base is not in one place (Spiegel et al. 1996b).

${ }^{4}$ While phrased in terms of an idiom of biological relationships, kinship here is thus not at all about biology - nor, indeed, is it always about readily traceable genealogies. It is about a flexible definition of relationships and of the normative roles associated with various social statuses
} 
activities, people called upon, and took as members of their social networks, only some whom they regarded as kin from earlier interactions and from genealogical knowledge. I also show how people created kin of others with whom they had intense reciprocal relationships, with whom they created social networks, but with whom their genealogical linkages were tenuous or non-existent. The ethnography also reveals instances when such kinship constructions were abandoned or collapsed.

The ethnography comprises case material from a small non-random sample of households studied by Anthony Mongameli Mehlwana and myself in the early 1990s. I begin by focusing on uses of kinship in the migration process and consider people's use of kinship in their everyday lives in their efforts to achieve urban domestic consolidation. I then turn to how people use kinship (and clanshipbased) terms to reinforce their reciprocal relationships, and how doing so reflects their understanding of the nature of kinship. I conclude by considering the implications of my findings for interpreting kinship in contexts of contemporary South Africa and then commenting on the significance that has for kinship studies generally.

\section{Kinship and the migration process}

Almost all adult and teenage members of the domestic units in our small sample were born outside Cape Town and had therefore migrated at least once. Many had oscillated between rural and urban areas, between and within different urban areas, and between various rural areas.

Seen in aggregate, migration had led to greater urbanism, with ever larger numbers settling in cities such as Cape Town on an increasingly long-term, if not permanent, basis. From the micro-experiential level, however, it became clear that - as in other industrial and developing contexts (see, for example, Ferguson 1990a; 1990b; Smith and Wallerstein 1992; Berry 1993; Grieco 1995) many individuals and domestic groups maintained continuing contacts and dependencies within and between urban and distant rural areas. Social structural constraints, the nature of people's support networks and how they understood their location in the broader political economy all militated against urbanward population movement and depletion of the rural population, at least until the mid-1980s when apartheid's urban influx control was abolished (Oliver-Evans 1993) and increasingly large numbers of women began migrating to towns.

The following cases illustrate how the networks and dyadic relationships that people created and relied upon to manage their migration experiences were often (although not exclusively) constructed around notions of kinship.

Many South Africans' first experience of migrancy was when they travelled as young children to live for extended periods in various parts of the country and with

conventionally associated with genealogical linkages. It reflects the lasting legacy in anthropology of Morgan's (1870) work on kinship terminologies, through which he came to understand the flexibility of kinship, foreshadowing - very far ahead of its time - an overlooked facet of 1950s structural-functionalist kinship studies in Africa, and, more significantly here, a central feature of 1990s post-structuralist analysis in which people came to be seen to invest time and energy in the cultural constructions of their relationships. 
a variety of relatives (Spiegel 1987; Reynolds 1989; 1993; Jones 1993; Meintjes et al. 2010). ${ }^{5}$ Processes of dispersing children among relatives meant often repeated disruptions of early close relationships and children having to establish relationships with genealogical relatives whom they did not know, or with individuals with whom they could activate only latent clan-based kinship links (Kotzé 1993; Reynolds 1993; Ross 1995; 1996; Van der Waal 1996; Henderson 1999).

These kinds of early disruptions of close relationships are exemplified by the experiences of fifteen-year-old Noxolo Mlingwa. ${ }^{6}$ They demonstrate how the routes children travelled reflected the significance of established and "putative" 7 genealogical links for the adults who directed their movements, and how children themselves understood their ties to caregivers.

\section{Case 1: A child shunted around}

Noxolo Mlingwa was born in 1978 in the (then) Transkei homeland. Her mother, Nomakhaya, was unmarried and living in her natal home although, by 1992-93, Noxolo's maternal grandmother, Nomachule Mlingwa, headed a Khayelitsha household.

In 1984, Noxolo's mother 'disappeared'. Soon she accompanied her mother's mother's brother - she described him as grandfather (tat'omkhulu or father's older brother; lit: big father) - to his Gauteng workplace: 'there was no one at home who would take care of me. Tat'omkhulu was living in Johannesburg ... and I asked him to take me to Gauteng when he came for a visit ... because my mother had gone to I don't know where. I've never seen her since.'

Noxolo reported living contentedly for three years with her tat'omkhulu and his wife in their furnished brick home in Gauteng. But the old people's relationship soured and she and her tat'omkhulu left, as the house was registered in the wife's name.

Noxolo was then placed in the care of Buyiswa, a nearby shack resident she understood to be her maternal grandmother's brother's daughter. From the account of her grandmother, Nomachule, Buyiswa was simply a friend of Noxolo's tat'omkhulu. Yet, because Buyiswa's mother and Nomachule's mother (Noxolo's maternal grandmother's mother) were of the same clan, they had activated a 'putative' kin relationship: Nomachule and Buyiswa were reciprocally matrilateral parallel cousins, and Noxolo described Buyiswa as her mamokhulu (lit: older mother, or mother's older sister, but in this case Buyiswa was genealogically Noxolo's maternal grandmother's older sister).

When Noxolo's tat'omkhulu remarried in Lesotho, he fetched Noxolo to live there. She did so for three years, until he died. Noxolo then returned to Gauteng to live with her tat'omkhulu's first wife.

Although in familiar territory, Noxolo found that 'things were not very well [there] ... Auntie was struggling [unemployed] and we did not have enough to eat. Also I was not admitted to school ... because I arrived in the middle of the year. I had to stay home.' Noxolo remained there for thirty months until her matrilateral cross-cousin discovered

\footnotetext{
${ }^{5}$ The imperatives leading to such child migration have been significantly exacerbated by the AIDS epidemic, which was in its infancy at the time the ethnographic data presented here were gathered.

${ }^{6}$ All personal names used here are pseudonyms in accordance with agreements reached with informants who wished to remain anonymous.

${ }^{7}$ I have used adjectives such as 'putative' and in some places 'fictional' while aware of the implication that these reflect an etic perspective - thus my use of quote marks.
} 
her predicament and wrote about it to his paternal grandmother in Khayelitsha, Nomachule. Grandmother Nomachule borrowed money from her employer and sent another granddaughter to fetch Noxolo, now aged fifteen. Noxolo expressed horror about Khayelitsha's destitution and her lack of friends there. She pined to return to her earlier comforts, even if it meant living with Auntie who had neither resources nor the will to care for her.

An important reported cause of children being shunted between kin was their parents' own intermittent and sporadic migration practices. As shown elsewhere (Spiegel 1986; 1987; Sharp 1987; Reynolds 1989; 1993; Jones 1993; Van der Waal 1996), the exigencies of migrancy meant that many African children could never expect regular and reliable support (either material or emotional) from their caregivers, or consistency over time as to who those caregivers were. It also meant, as Case 1 indicates, that long dormant kinship relationships were (re)vitalized or, in some instances, new ones constructed around latent clan-based kinship links.

Most adults' migration experiences were also marked and facilitated by the use of kinship, both readily traceable genealogically and potentially 'putative'. Kinship constructions were important in adults' migration experiences and the relationships around which these hinged, as is illustrated by Noxolo Mlingwa's grandmother's migration history.

\section{Case 2: An old lady comes to town}

Nomachule Mlingwa was in her forties when her husband abandoned her and she fled to the then Transkei seeking work in the Western Cape. First stop was a small town near Cape Town. She stayed with people from 'home' - relatives of her older sister's husband - and worked as a domestic. She then moved to Cape Town and lodged during the weekend with her sister's daughter in a formal township house. On weekdays she 'lived in' at her places of domestic work. Later, she changed her 'lodgings' address to the Langa home of a man she described as her malume (lit: mother's brother) because, she said, he shared her mother's clan name. Then her daughter established herself in a shack and Nomachule relocated there, slowly assembling her various children and grandchildren around her from places in the Transkei and elsewhere around Cape Town. They moved, en famille, to Khayelitsha when they obtained a site in 1991.

\section{Case 3: To town for a child's health}

Nomsa Malibongwe arrived in Cape Town after her husband abandoned her and four children (one severely physically handicapped) in the Transkei. Advised to seek appropriate treatment in Cape Town, Ms Malibongwe arrived, destitute but with an offer of accommodation with a childless woman she had known as a child and had recently met again in the Transkei. Ms Malibongwe called her 'sister' because, she explained: 'Her mother and my mother are sisters, but not in a direct way ... Her mother is my kanina' (lit: matrilateral cross-cousin). But the relationship was strained and, when Ms Malibongwe found a job, she purchased her own shack and left her kinswoman and erstwhile housemate (see below).

Manona (1991) showed that in-migrants from neighbouring farming areas to Grahamstown in the Eastern Cape followed the migration and urban settlement paths of close kin. Amy Saltzman (2013: 132) has shown that the same thing occurred much more recently among newly arriving migrants in Cape Town. Her data corroborate our early 1990s Khayelitsha findings that many individuals had 
done the same, providing themselves with a sense of a secure haven as they moved into Cape Town. Case 4 provides a description of the ways in which close kin were used in the early to mid-1990s during an in-migrant's first period of urban residence.

\section{Case 4: Relying on close kin on arrival in town}

Arriving in Cape Town to join her husband, Nolusapho Sawila had insisted, she told us, that they move from the shack where he had been lodging with a distant relative to be close to her own sisters. First they built a small shack on one sister's site. Having accumulated materials, they removed and rebuilt an extended shack on their own nearby site. Throughout, they remained close to two of Nolusapho's sisters' sites: 'I was a neighbour to my sisters ... My sister was on one side and another was on the other side. And we all knew each other.'

Yet, when they were all subsequently forced to move to Makhaza's site and service area, the site allocation process separated them, something Ms Sawila resented because 'we stay among people we do not know ... And I do not know them even now. We do not ask for sugar or salt from them, and they do not ask us.' But she did travel frequently to visit her sisters.

The above cases illustrate the importance of kin for people who were first settling in town, a common phenomenon worldwide. Importantly, in Khayelitsha, it was relatively close kin who were readily traceable genealogically, or people known from home, to whom newcomers turned during an early urban phase. Readily traceable close kin were selected because the first settlement process allowed people little time to establish relationships through acts of repeated reciprocity. Establishing such relationships takes time, as does reinforcing those that prove reliable by characterizing them as kin-based. Constructing genealogies by activating previously latent clan-based kinship links cannot occur overnight. As Nomsa Malibongwe (Case 3) said, when explaining why she had stayed with a 'sister' and 'homegirl' she now scorned: 'At the time I had just arrived in Cape Town [and] I did not know anyone.'

Yet close kin could also have a negative value. Having established herself in Cape Town with her mother's help, Doris Mlawu made every effort - including selling her mother's Cape Town shack - to force her mother to retire in the Transkei. In part, Ms Mlawu explained, she wished to ensure a continued vicarious presence in the Transkei (cf. Ferguson 1990a for Lesotho). Further, she felt taken advantage of by her mother's continuing presence in her own urban home once the mother no longer earned an income: 'I do not want her here because during all those years I have not seen anything that she did for us.' Clearly, the 'moral' component of an assumedly very close kinship relationship between mother and daughter had become quite tenuous - precisely because, for a long time, it had not been backed up with the material reciprocities Ms Mlawu believed necessary to underpin those relationships. This, together with a lack of significant emotional support, was a consequence of Doris's mother having settled in Cape Town when widowed, and neither remitting to nor visiting her children in the Transkei. As Doris said: 'Ever since I grew up my mother has been here in Cape Town. I think she left me when I was six years old. She was a resident here for many years and I did not know her.' Yet Doris was willing to accommodate her 'putative' cousin (mzala or cross-cousin) and old friend (Case 5) with whom she had a proven reliable reciprocal relationship with both material and emotional components. 


\section{Case 5: Making kinship out of friendship and clan links}

Magareth Mbiza had previously accommodated Doris Mlawu in her Transkei backyard. Having established their clan relatedness, they had constructed a putative genealogical link, reinforcing their mutually supportive relationship. Doris's mother's mother and Magareth's father shared a clan name, thus rendering Magareth a classificatory maternal grandmother's brother's daughter of Doris, a link enabling them to call each other mzala (cross-cousin) by ignoring the genealogical generation difference.

When Doris visited the Transkei from Cape Town, she encouraged Magareth to join her. Magareth's 'birth sister' was already living in a small formal house in Khayelitsha and Magareth spent her first five months in Cape Town there. That sister helped find her domestic work. Later, Magareth moved into mzala Doris's shack and, using Doris's connections with the local street committee, subsequently acquired her own site and built a house nearby, using materials for which mzala Doris stood surety.

\section{Kinship and the everyday life of domestic consolidation}

Most people in the industrial world expect that, over time, they will establish and consolidate domestic units that provide them and their dependants with mediumto long-term security. For migrant workers, there has always been some ambivalence about where these units should be located, as there has been about the forms their assets should take. Generally, however, the expectation has been that such units should be able to provide for those who regard themselves and each other as co-members and, in the longer term, for those who have contributed to the common resource pool on which the unit's members have understood that they should be able to draw.

Domestic consolidation involves building social and cultural-emotional as well as material resources. It includes the creation of social networks according to and in turn influencing - culturally accepted norms of association. Analytically, therefore, the domestic consolidation process underpins, and runs parallel to, the developmental cycle of the domestic group (Goody 1958). Yet no domestic group is necessarily associated exclusively with any particular domestic space or fixed set of material resources or real estate. Moreover, the individuality of each particular attempt at domestic consolidation and at creating a household - in what Seekings (2008) calls a social project - along with the vicissitudes of dependence on migrants' earnings in an unstable and insecure labour market, have meant that these kinds of domestic groups have tended to have fluid boundaries. As Saltzman (2013: 184) illustrates, the process of what McAllister (2001) called 'building the homestead' is one that sometimes results in a household comprising a diversity of domestic houses in various locations, in urban and rural areas. That said, however, it is also clear that not all people's domestic consolidation attempts have been anywhere near so successful from a material - or, indeed, a socialrelational - point of view (see Spiegel et al. 1996a; 1996b), nor that they necessarily produce long-term dependable relationships. It is in this kind of context that people resort to notions of kinship and the morality implied in it to attempt to stabilize their relationships.

In the illustrative examples below I demonstrate how and where kinship - both genealogical and activated from latent links - was used in, and affected, everyday practices associated with domestic consolidation as people attempted, more and 
less successfully, to create and/or sustain social relationships and networks of support.

All the sampled domestic units had relocated to Makhaza, which was then a new site and service area, no more than two years before the field research. The site allocation process had been insensitive to their previous local neighbourhood network dynamics in what were called transit camps - temporary residential areas for those being relocated from land-invasion areas to serviced sites in areas designated for settlement by the then still hesitatingly transforming state. People had therefore had to establish new urban neighbourhood networks in conditions some found unsatisfactory.

Some women attending a local nutrition centre had constructed such a network. Importantly for the present discussion, they expressed their understanding of these networks, which commonly involved shared childcare, in terms that are conventionally associated with family and household.

Nomsa Malibongwe (Case 3), Nolusapho Sawila (Case 4), Nowandile Mthetho and 'Mamotaung Ndlovu had all met at a nearby NGO-run nutrition centre. At that time, all were materially destitute and all had malnourished children. Each independently identified the other three (among others) as people to whom she could and did turn for everyday assistance. Their lists all also included Nowandile's neighbour, Nomachule Mlingwa (Case 2).

The five women's mutual support structures included shared childcare duties: the young children of their respective households passed about between their homes quite frequently, creating a sense for the children of an almost seamless continuity of family between the various households.

Each woman was clear which children around her shack 'belonged' to her household. Each was also explicit about how extensively those children could eat and sleep, sometimes for days at a time, in the others' shacks, and how they reciprocated by letting other children stay with them, sometimes for extended periods. Discussing the practice, they reflected a sense of 'putative' - even 'fictional' - kin-type links between them. As Nomsa Malibongwe explained:

One who often visits my house is the child of Sisi [sister] Nowandile ... He sleeps here often. A week does not pass without his having slept here ... I do have other [adult] visitors and sometimes they want to stay over. But I send them off [embarrassed laugh], because I do not know what [food] to give them; and I do not have a place for them. [But] Khayalethu [Nowandile's son]! I regard him as one of my children. He sleeps where my children sleep.

The boy's activities exemplified many other children's practice of frequently eating and sleeping over, for days at a time, at the homes of neighbours in their parents' mutual support networks. The adults understood the practice for precisely what it was: opportunities for those temporarily unable to sustain their children to have them fed and cared for, albeit only minimally, by associates and neighbours. It was understood, too, that such arrangements had to be reciprocal: that when they had obtained resources they would help others' children. Moreover, it was tied to an ideology of common household membership. So, when Ms Malibongwe said of the boy Khayalethu, 'I regard him as one of my children,' she was indicating a cultural understanding that the reciprocities involved in shared childcare should be understood in kinship terms. 
Yet the relationships that constituted these networks were fragile, which indicated that using notions about common kinship did not always successfully reinforce the networking bonds, especially when some individuals ended up being more successful in their urban consolidation efforts than others. When a member of a network in which everyone was all but penniless found a regular job, and began living a little more comfortably, the tendency was for her to break ties with the rest. This happened with Nomsa Malibongwe, whose ten years of schooling, versatility in English and drive enabled her to pull herself out of penury.

\section{Case 6: Security for one breaks the network}

Nomsa Malibongwe's skills and abilities were identified at the NGO-run nutrition centre, and she was encouraged to join a literacy teachers' training programme. Once qualified, she found employment and began successfully to consolidate her urban domestic arrangements, moving from her classificatory sister's shack and establishing herself in a shack on her own site (Case 3). She simultaneously distanced herself from her erstwhile friends, creating a new social network with others of similar material status.

Earlier, Ms Malibongwe had explained how she had avoided turning for help to her wellestablished kin in Cape Town because she had feared that her inability to reciprocate would mean that they would despise her and, she said, because she did not want obviously to use the kinship connection purely for material benefits. Her sense of pride was evident when, discussing where her own children might sleep out, she had explained that they might do so at 'sister' Nowandile Mthetho's equally poverty-stricken home but not at better-off urban kin's homes.

Soon, however, Ms Malibongwe's new reliable income had allowed her to extend her shack and take her disabled child out of the establishment where the young girl had previously been placed, to be housed at home and to receive the 'mother's love' Ms Malibongwe said she needed. Then she managed to pay fees for her son's initiation in the Transkei, a son of whom she had earlier said: 'The problem [reason] he must study [in the Transkei] is that I cannot afford the costs of education. I gave him over to my brothers to educate him for me.'

Her erstwhile friends meanwhile began to resent Ms Malibongwe because, they said, she no longer had time for them or their children. In Nowandile Mthetho's words, not only did 'she no longer visit us. Even her children [who] used to come and visit [the boy] Khayalethu here no longer come. It was only my children who used [recently] to go there. But I had to put a stop to that because the other day Khayalethu came home and said that Ms Malibongwe did not give them anything to eat while she gave her own children food.' Novumile Sangweni added: 'Ms Malibongwe no longer comes to my house either, even though I stay near her. The only time I see her is when she is in the house alongside mine ... That woman [the neighbour] is her only friend. You will find her children playing there. When she is at work, her children go there since she comes home late. She has her suppers there. The only thing they do there is gossip. I once went there to borrow a cup of sugar. She said she did not have one, even though I could see a big bag of sugar.' 'She was my friend in the past,' added Nowandile Mthetho, who had introduced Ms Malibongwe to the nutrition centre, 'but she no longer is. Because she is working, she sees us as a burden on her. It means she was not really a true friend of mine. She was a friend [just] because she was in the same situation as mine. But I tell you inkunga ilala kwiintaba ngeentaba [mist lands on different mountains: that is, luck lands on different people at different times].' And the older woman, Nomachule Mlingwa, added: 'Women as lucky as Mother Malibongwe are turning their backs on their own friends and people. I remember when she had just come to 
live in this area. She was as poor as we are ... I was working at the time and she was not. I used to give her some food and other things. But she has forgotten all that now. Maybe she no longer sees herself as being in the same situation as we are. She is working and earning money every month. She avoids us because she thinks we are going to borrow from her. Even if I'm as poor as I am, I still like myself [have self-respect]. If someone thinks she is better than I am, then I won't bother her.'

While these women continued to regard one another's children (and grandchildren) as their own, they no longer did so for Ms Malibongwe's children. Earlier they had described her in kinship terms. Now, they said, she was no longer even their friend. They had abandoned hope of activating any kinship-based moral responsibility in their relationships with her: breaches in reciprocities and conflicts over money (cf. Bähre 2007) had precipitated the repudiation of kinship and friendship connections and they no longer referred to their relationship with her in kinship terms.

Carol Stack's (1974) discussion of child-keeping - the sharing and frequent transfer of responsibility for childcare among poor African-American households and individuals - demonstrated how ideas about what constitutes kinship come to be pragmatically redefined. One result (Stack called it fictive kinship) is that people use various kinship terms to describe others in whose households they live and who support them materially, despite their having no genealogical links.

Stack's argument cannot, however, be applied directly to the present case. IsiXhosa, most Khayelitsha residents' first language, has long used kin terms for both address and reference in widely divergent relationships (Hunter 1936: 53), not just genealogically traceable ones. In the present instance, Ms Malibongwe's statement that she 'regard[ed] him [Khayalethu] as one of my children. He sleeps where my children sleep' reveals the use of kinship notions as an ideological underpinning to reciprocal support practices among very poor people in areas such as Khayelitsha, rather than simply, as described in relation to the past, as 'polite modes of address' (ibid.).

The fact that people also used ideas about clanship (see Case 5) indicates yet more clearly a popular concern with constructing such relationships in kinship terms, as the case of two locally resident men, Oliver Ntyatyambo and Geoffrey Kheswayo, demonstrates. Having become close friends and having also discovered that they were of the same clan, they regarded each other as brothers. When Oliver was murdered, Geoffrey and his wife assisted Oliver's widow by accommodating her and her children in their home for many months. Having recognized and activated a latent genealogical relationship based on common clan membership, the two friends extended it to link their wives and children. By doing so they showed the cultural potency of kinship notions, precisely as they were being constructed.

The next two cases demonstrate this further. One reveals the importance of clan-based links in desperate times; the second how much more significant they may be than genealogically closer links.

\section{Case 7: Clan-linked kin in times of crisis}

Unemployed, Mr Dengana Ndlovu spent a great deal of time in shebeens (local taverns). His wife and child attended the nutrition centre. Their shack was cramped, tiny and destitute. Soon after we first met them, his wife had left him, having found a job and choosing to use some of her wages to return her children to the Transkei, to be cared for by her mother. 
Dengana, left to fend for himself, burned himself badly with boiling water and was cared for by two men, both of whom he regarded as kin, as well as by the girlfriend of one of the men. One man, Sisa, Dengana called mzala (cross-cousin) because Dengana's clan name was the same as Sisa's mother's, making Dengana's father and Sisa's mother clan siblings and Dengana's father Sisa's classificatory mother's brother (malume). The second man, Mfundo, who had taken Dengana by car to the clinic, Dengana described as kayise (brother or sibling). They had been childhood neighbours and, although not genealogically close, had constructed their relationship around their shared clan name. Dengana described Mfundo as his father's younger brother's son, which in classificatory terms is his junior brother (or what is sometimes described colloquially, in order to render the relationship into English, as a cousin-brother).

Desperate, Dengana Ndlovu found his clan relatives were crucial. Asked to name those he regarded as close local associates whom he could readily trust, he explained: 'There are many people I know here in Makhaza but I do not know their [first or sur-]names. We men call each other by clan names, so that names are unimportant. What is really important is the clan name, and to a lesser extent one's place of origin.'

For Doris Mlawu (Cases 5 and 8), clan-constructed kin who offered support were more valued than close genealogical kin. She distanced herself from her own mother but established close relationships with people with whom she could create 'putative' kin links. She complained that, despite their relative wealth - which they had not shared with her - her genealogically traceable kin were effectively useless in her struggle to sustain herself. Those she depended on were, in contrast, just associates. But she had constructed kin links with them by activating previously unrecognized latent clan-based linkages.

\section{Case 8: Clan links in various directions}

Ms Mlawu's father was the second son of the Thembu paramount, Mtirara, and brother of Sabata, Mtirara's successor. Yet she derided the usefulness of the links. Her father had died when she was three, and Sabata had taken her and her siblings in. But soon Sabata fled into exile from apartheid to be replaced by Bambilanga, Sabata's younger brother and political opponent, who offered no further assistance to Doris's mother. The mother then left to work in Cape Town, leaving Doris in her mother's brothers' care.

Case 5 describes Doris's reciprocal relationship with Magareth Mbiza and the imputed genealogical link that made their relationship salient. Doris also constructed and activated other such links. They are represented in Figure 1, which shows how Doris's urban network was based on the imputation of kinship ties. Significantly, Figure 1 excludes various genealogically close kin whom Doris identified when asked, but of whom she said: 'They are my relatives who are not very useful because they don't help me at all.' She thus excluded them from her contingent social network, thereby perceptually placing them at greater social distance than the 'putative' kin she included, and of whom she said: 'These are the ones who are very useful to me.' (They are shaded in the figure, which also includes (unshaded) symbols identifying various individuals through whom the network members were linked but who were not part of Doris's social network.)

Such diagrams graphically represent the use of kinship and clanship to underpin and reinforce contingent social networks. The 'putative' relatedness of shaded individuals through clanship-based links reveals how a culture of kinship was being called upon to make contingently constructed networks socially salient. 

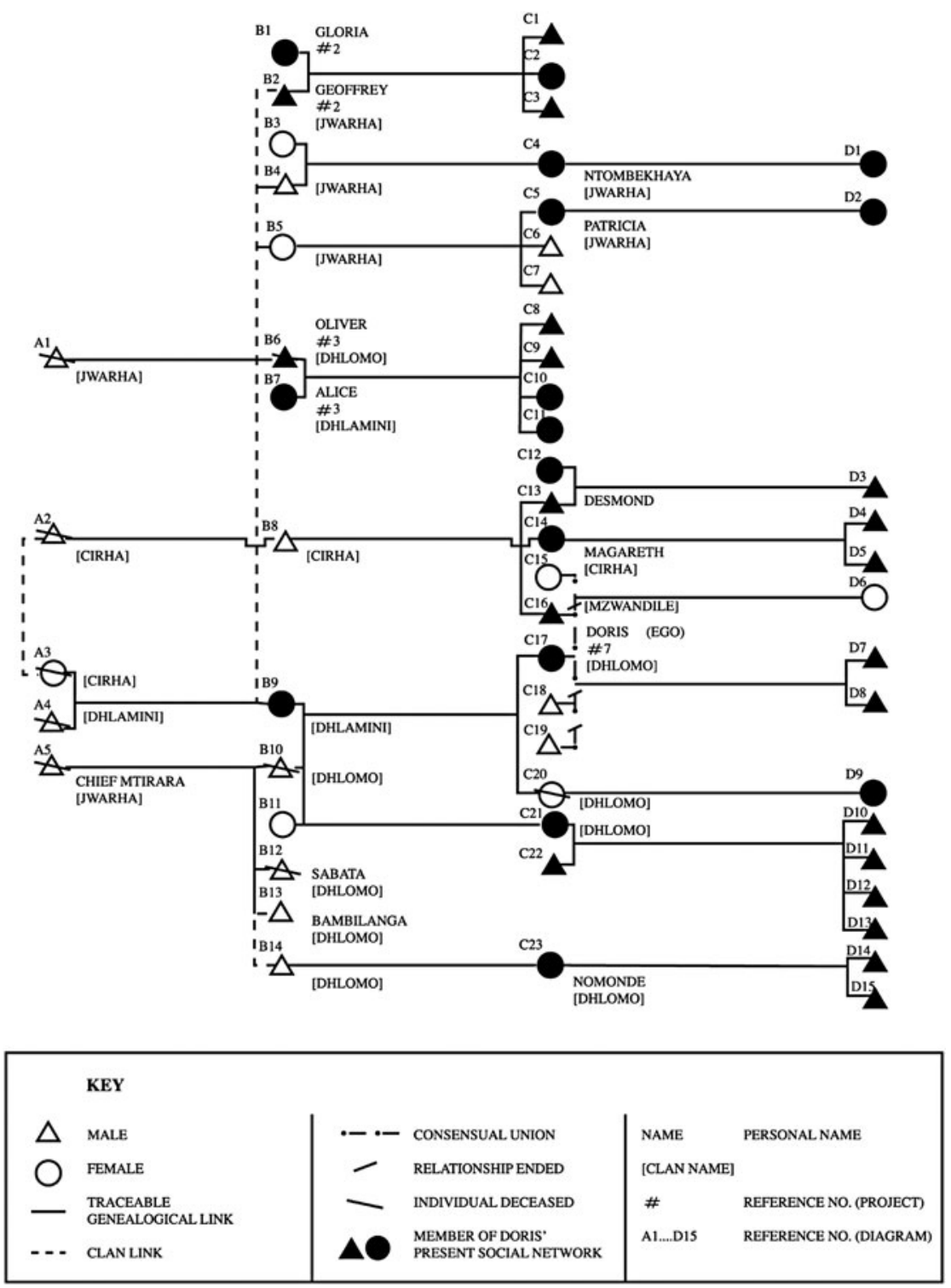

FIGURE 1 Doris Mlawu's social network in (putative) genealogical terms.

Figure 1 also represents parts of the social networks of two others: Gloria Kheswayo and Alice Ntyatyambo (B1 and B7 respectively), although both had networks stretching elsewhere. Because Alice had been born in Cape Town she could appeal to her local natal kin and childhood friends in times of desperation, as occurred when she fled from her Makhaza home. Yet, just as Doris had attenuated 
her relationship with her mother, Alice preferred to keep her distance from genealogically close kin (including her mother who lived in a formal township).

Such diagrams cannot show detailed contents of the relationships they illustrate and space constraints prevent discussion of the substantive extent of those indicated in Figure 1, although Doris's presence in many examples used reveals some such detail.

\section{Reconsidering kinship, clanship and reciprocity}

The material above demonstrates two things. First, that the effective bonding agent between poor people such as the 1990s residents of Khayelitsha's Makhaza is their reliability as exchange partners. This occurred in generalized reciprocal relationships that were thoroughly socially embedded, with little or no need for close accounting of exchanges. Yet they were clearly unsustainable if such material transfers always went one way (cf. Sharp and Spiegel 1985).

Secondly, and notwithstanding the first point, the ethnography above shows how poor people in Khayelitsha gave meaning to the most effective of these bonding agents: how they embedded and sedimented them culturally by constructing them in kinship terms. Their doing so reveals the resilience of an ideology of kinship as a fundamental signifier of relatedness and shows how the morality of kinship (Bloch 1971) remains a potent resource, used and applied to otherwise purely associational and materially based transactional relationships.

The second point also demonstrates that people who apprehend kinship ties as based in reciprocal relationships and act accordingly share a cultural model that recognizes the potential for making kin of many others in their social environments and that simultaneously values close kin as normatively more morally dependable than distant kin. This becomes evident when one considers the practice of using kinship terms that effectively describe 'putative' kin as close kin, and of not enunciating the imputed nature of their relationships. That they used close kin terms to make 'putative' kin socially close indicates a norm according to which genealogical proximity should mark social reliability - a point made by Ross (1990) in relation to membership of rotating credit associations. ${ }^{8} \mathrm{Had}$ people linguistically indicated genealogical distance from their 'putative' kin, they would have said that they were 'only' distant relatives. Much as Launay (2006) describes in relation to the ways in which joking relationships were used contingently by Dyula people in Côte d'Ivoire, the fact that Khayelitsha residents described their 'putative' kin in close-kin terms meant that they brought them perceptually close and thereby revealed a culturally constructed hierarchy distinguishing close and distant kin, a hierarchy that was flexible enough to remain unconstrained by the structures of neatly traced genealogies. ${ }^{9}$

How does this flexible use of kinship as a cultural resource relate to clanship in Southern Africa, particularly in its Nguni and Xhosa idiom? If, as is anthropologically commonplace, kinship is not simply a description of biological

\footnotetext{
${ }^{8}$ 'The operational potential of kinship terms derives from the fact that they have a moral meaning originating in the general belief system of the culture' (Bloch 1971: 80).

${ }^{9}$ I am grateful to Sally Frankental for helping me to recognize this point.
} 
relationships, what are the particular cultural artefacts through which kinship is constituted as a resource? And what ideas underpin the notion that close association can be reinforced by appeals to the language of kinship?

In Southern Africa, a particularly important cultural construct for this purpose is one described in English as clanship. The broader Nguni-speaking population shares an understanding that everyone is associated patrilineally with an isiduko (plural: iziduko; inadequately translated as clan), identified by its isibongo (plural: izibongo; clan name) (Preston-Whyte 1974: 201). ${ }^{10}$

Classical ethnographies describe iziduko as social categories comprising people claiming patrilineal relatedness without formally tracing a common line of descent (Wilson 1969: 116-17; Preston-Whyte 1974; see also Hammond-Tooke 1985a; 1991). Each isiduko is identified by its own isibongo, a putative - and commonly distant - ancestor's name: 'Clans, consisting of descendants in the male line of a named but distant and often mythical ancestor, are found in all Nguni societies' (Preston-Whyte 1974: 178).

People sharing an isibongo can be found scattered across the subcontinent (Wilson and Mafeje 1963; Wilson 1969; Hammond-Tooke 1991), a factor that makes any isiduko too large to constitute a corporate group. The dispersed nature of clans predates colonialism and the impact of labour migration. It is unlikely that clans ever occupied particular areas of land exclusively (Wilson 1969: 117-18). For Nguni people, clan exogamy rules and the principle of patrilocality would have rendered exclusive occupation of an area impossible, as every married woman would have had to be part of a clan other than that of her husband. Moreover, what Wilson describes as 'the absorbtion [sic] of strangers ... some being provided with cattle by the chief they acknowledged' (ibid.) - also known as ukukhonza (to serve) - meant that any one area could be occupied by people of various clans. While precolonial polities were described by the clan names of their respective leaders, their constituent members - the leader's subjects - were always of various clans, although their political allegiance was to the particular polity's chief (ibid.: 117-18; Hammond-Tooke 1991).

In precolonial times - and to some extent still today - clans functioned for two important purposes: among Nguni people, for defining categories of people one could and could not marry (Preston-Whyte 1974: 178, 192-3) or with whom one could procreate; and, for both Nguni and Sotho, for ritual purposes. In terms of Xhosa marriage rules, one cannot marry someone of one's own, one's mother's or either of one's grandmothers' clans. This exogamy rule requires

\footnotetext{
${ }^{10} \mathrm{Clan}$ descent is also traced by members of the other large language-based population, the Sotho. But in that case it is from totemic rather than human eponyms, and exogamy rules are far less restrictive. The Sesotho and Setswana word translated as clan and clan name is seboko. John Comaroff (personal communication, April 2000) has said that today 'Tswana also put a great deal of stress on kinship ... but they do not do it with reference to clan membership'. He has gone on to ask whether 'the relative stress on exogamy ... has configured the world in such a way as to make it especially significant [in the Xhosa-dominated world of Cape Town]'. My own experience in Lesotho and some Basotho-dominated areas of the Matatiele district in the former Transkei are that clan names were commonly used to mark kinship when genealogical tracing was not possible. The question Comaroff raised then becomes one that requires detailed comparative historical contextual analysis to answer.
} 
exclusion, as potential spouse or procreative partner, of anyone from each of four clans (ibid: : 192).

Clanship was also important in ritual, particularly among Cape Nguni (Hammond-Tooke 1985b; 1991). Submissions and sacrifices to ancestors required, firstly, that a senior clansperson should officiate and, secondly, the participation of one's co-clanspeople in one's neighbourhood. In such moments, clusters of clanspeople became temporary corporate groups, but only for ritual purposes. And such purposes most certainly did not imply incorporation, even temporarily, of all people everywhere with the same isibongo (Hammond-Tooke 1985b; 1991).

While both functions are still part of clanship, the isibongo (seboko in Setswana and Sesotho) has another quite different importance in the contemporary industrial context. It provides all Africans in Southern Africa with various named sets of people across the subcontinent with whom they can reinforce demonstrably successful associational relationships. Given poor people's extensive mobility, it provides an important resource. Arriving migrants have long been able to call on people of their own isibongo for assistance, even if only temporarily and depending on the contingent circumstances of those who provided support. As PrestonWhyte (1974: 201) suggested:

[T] oday [the 1960s and 1970s], common clanship amongst the Nguni provides an initial facilitating link between individuals, especially useful to the stranger coming to town ... [and] ... clanship may be used as a basis for a more demanding relationship should there be the need and should both partners be agreeable.

More importantly, people underpin their associational and reciprocal relationships established in urban environments by constructing them in kinship terms that are built on clan links, and by inculcating them with moral obligation. Of course, not all those sharing one's own isibongo can be relied upon to provide support: even close relatives may not provide assistance. Yet, from the evidence presented here about people's tactical use of kinship during the period of transition from apartheid, it is clear that reliable relationships can be reinforced ideationally by imputing kinship (clanship). They thus invoke a morality associated with kinship, importing and embedding it into those relationships.

The examples above describe how this occurred in the construction and reinforcement of various dyadic relationships, albeit all located in wider social networks: when two individuals established a working reciprocal relationship and reinforced it by 'discovering' a clan-based genealogical link and redefining their relationship in kinship terms. Other examples show dyadic 'putative' kinship/clanship links spilling over to redefine inter-household relationships.

The use of clan-based linkages to construct and reinforce relationships does not, however, end with dyad-based network creation. Whole associational groups may consolidate around people sharing a few clan names, as exemplified by a $1990 \mathrm{~s}$ Khayelitsha-based burial society.

\section{Case 9: Kin links consolidate a corporation}

Ikhaya Lethemba (House of Hope/Trust), a burial society in Makhaza, was established in 1991 after many of its members had been relocated there and after their previous burial society had collapsed. 
The earlier society was established by a fishing company's co-workers, all from the Ciskei settlement at Sada, an apartheid relocation area for ex-farmworkers where relationships between residents were new and shallow with no strong bonds of trust. As a founding member explained, the association's 'home-boy' basis was insufficiently strong to hold it together when its members were relocated in town and dispersed from their common place of work, and when some leaders 'mismanaged' the society's funds.

Some ex-members who had settled in Makhaza then established Ikhaya Lethemba, a new burial society to help cover funeral costs in Cape Town only, and to provide emotional support to bereaved members. In principle, any trustworthy person in the neighbourhood could become a member. Yet, in practice, the fifty-strong membership comprised people of just four different clans, ensuring that all members could create at least 'putative' kinship and/or affinal links with one another by activating previously unrecognized clan-based ties. Indeed, the membership's composition resulted from the recruitment of new members who had demonstrated reliability as reciprocity partners and who were at least clan relatives of an existing member. That way, its leaders said, they could ensure the trustworthiness of all members, a trustworthiness built on the morality associated with kinship.

Ikhaya Lethemba offers one example of a whole network of relationships created and transformed into a corporate structure on the basis of a series of dyadic relationships reinforced by clan-/kinship-based morality. Yet, just as the dyads built around that principle were insecure, so too were larger networks subject to disintegration when their material basis could no longer sustain them; this point is applicable to corporations, such as burial societies, that are built on structures of contingent social networks. People may appeal to principles of kinship by imputing kin linkages through clanship and thus create a sense of moral obligation. Yet they know that they cannot expect the networks to survive material extremes.

\section{Persistence and its implications}

The ethnographic evidence presented above provides examples of people's use of a culture of kinship and clanship during the period immediately following South Africa's political transition from apartheid, when the apartheid-created uncertainties about urban living seemed likely to be overcome. However, over twenty-five years later, those uncertainties - and the insecurities that accompanied them then - have remained just as marked for vast numbers of the country's population. That is in part because the post-apartheid government has failed to make good on the promises implicit in its slogan of 'a better life for all'; in part because the AIDS epidemic has orphaned vast numbers of young people, rendering them particularly vulnerable; and in part because the South African economy's failure to grow - or as Hylton White (2013: 141) describes it, 'the long-term retreat of capital from the labour market' - has led to very high levels of unemployment that have resulted in people having to construct diverse relationships and create networks through which they sustain themselves (see Harper and Seekings 2010). Despite the state providing small amounts of child support, disability and old age grants to many (Ferguson 2015), there are vast numbers who remain in extremely precarious and impoverished circumstances. As a consequence, contemporary residents of Khayelitsha and other Cape Town townships, as elsewhere throughout the country, continue to use various tactics to underpin claims to relationships 
through which they seek material and often also emotional support and sustenance. In turn, that has meant that what I have here called the culture of kinship and clanship continues to have contemporary significance for structuring relatively large numbers of everyday relationships of mutual support and dependence; and that it continues to be used in ways described for the early 1990s period although it also often fails to provide, or stops providing, when the reciprocities that have underpinned it are disrupted or produce conflict (cf. Bähre 2007; Ferguson 2015: 69, 107).

An immediate example of kinship's use - frequently creating family conflict as much as solidarity - is the extent to which many young but unemployed South Africans claim kin-based attachments to old age and other social grant recipients in order to benefit from those grants. The fact that the sources of financial resources have changed with the new salience of social grants means, however, that the modes of constructing those kinship links deserve further careful study. Another example is of a young professional who, having recently struggled through a university's housing administration to find accommodation, was quickly accommodated when one housing administrator discovered that they shared a clan name. A third example is evident in James's (2012) account of the dangers that post-apartheid's aspirant speculative entrepreneurs face when attempting to profit from purchasing and reselling bank-repossessed houses in urban townships - precisely because of popular local-level associations of such houses with particular families and kin groups, and assertions about their moral right to remain resident owners, the 'logic' of commercial bank loans notwithstanding. ${ }^{11}$

Consider, too, the comments of an older part-time waged working woman who recently reported to me that she frequently finds herself being approached for help at her Cape Town township home. She explained:

I ask people who come to me, when they are struggling, where [in which clan] they would be entitled to eat ilunda [the portion of a sacrificed animal set aside for matrilateral kin and their clan agnates]; and, when I hear that that is a clan to which I am somehow - even distantly - related, I know I have an obligation to assist, because that is what my ancestors demand.

To this she added that - in much the same way as the case studies show - there are very many clans to which she is distantly related, and so she finds that she almost always has to accept that she has an obligation to help, even when she would prefer not to. Moreover, her comment about ancestors' demands resonates with what White (2002) has reported from post-apartheid Zululand, where people are moved to use resources to assist kin to enact various rituals and related activities

\footnotetext{
${ }^{11}$ Interestingly, while Siyongwana (2004) refers to the way in which informal moneylenders try to guarantee the repayment of loans through having their established clients act as guarantors for new clients they introduce, she makes no reference to kinship underpinning the guarantors' relationship with the new client. This suggests a need for a thorough kin-focused analysis of those kinds of relationships and of the extent to which such moneylenders (and other successful entrepreneurs) are able to avoid or evade the demands of kin - especially when, as Siyongwana (ibid.) indicates, close to 20 per cent of those moneylenders started out by using interest-free family loans.
} 
aimed at assuaging the concerns of ancestors regarding often long-past but unresolved social problems and relational omissions. ${ }^{12}$

As du Toit and Neves (2007) have also indicated, the reasons for the continuing significance of the culture of kinship especially among poor people in the postapartheid period are evident: persistent poverty and vulnerability in the context of a country with the highest recorded levels of income inequality globally. Yet the implications of this culture both for themselves and for others in the country are not so clear.

One implication, I suggest, is that analysts of any kinds of mutually supportive relations in the post-apartheid South African context need to be constantly aware of manifestations of apparently old cultural principles - as Murray (1981) pointed out long ago and as Ferguson's (2015) analysis has confirmed. This is particularly relevant in analysing when, and how, such relations appear to take new forms to accommodate changing circumstances. In the case of kinship relations, that is precisely because, as I have explained, these kinds of old-new relationships are based on a sedimented notion of kinship and clanship and are thus always constructed using 'forms of connection available in historically determinate social environments' (White 2013: 141) rather than idiosyncratically.

Another analytical implication is that a careful and thorough kin-focused analysis of the multi-stranded relationships between and within the country's elites both new and old - is likely to reveal a similar use of the culture of kinship I have described in this article. ${ }^{13}$ That is because persistence of a culture of kinship may well be what underpins the political and economic nepotism, and its associated corruption, that has marked South Africa's recent political and economic history, and that in turn has led, at least in part, to the country's very high levels of inequality (as indicated by its high Gini coefficient). ${ }^{14}$ Similarly, such a

\footnotetext{
${ }^{12}$ The same woman further highlighted the persisting contemporary significance of clanship and the kinship principles associated with it for justifying relationship building and maintenance - at least from her own idealistic (traditionalist) perspective. That was when she said that many present-day youngsters, being ignorant of anything more than their own clan membership, often fail to establish the clan affiliations of their sexual partners, especially affiliations with a maternal or grand-maternal clan. In cases where offspring from consequent clan-incest relationships prove to be socially unruly individuals, she pointed out, those individuals need careful guidance through ancestor-appeasement processes and recognition of how their behaviour offends the ancestors - so that they can learn the significance of kinship and clanship for relationship building and maintenance; and about the importance of ancestors, and one's relationships with them and with one's kin, for ensuring that all one's relationships are sufficiently wholesome to ensure mutual support of all those involved.

${ }^{13}$ Krige (2011) touches on the issue in relation to the relatively precarious new aspirant middle class of Soweto. But we require a broader study as well as one that considers the extent to which there is continuity in this regard between the country's precolonial and early colonial-period elites and the present ruling elite. Ferguson (2015: 144-6) has indicated a possible way in which we might proceed.

${ }^{\mathrm{P}} \mathrm{My}$ thanks to David Coplan (personal communication, May 2004), who pointed out to me that if kinship is, as I argue, a crucial defining feature of relatedness for social network construction and manipulation, it probably also characterizes the lives of the less poor and is the basis of cases of contemporary nepotism. Also see Ferguson (2015: 97), who points out that social relations of wealth distribution in Africa have been described in various terms, corruption being one. Note that I am not suggesting here that this is the only cause of the country's very high levels of inequality, which are significantly also a product of persisting control and domination of much of the economy by individuals from the minority white part of the population.
} 
culture of kinship may also be underpinning present-day conflicts over national and ruling party leadership, where there appears to have been a process of dynasty construction that draws on and is driven by ideas about kinship, clanship and, it seems, ethnicity and tradition. ${ }^{15}$

\section{Conclusion: what is kinship? Lessons from Khayelitsha}

I now return to the more general points this article raises about kinship and how to understand it. The kinship described here is not biology. It is neither fictive kinship where adoptions filiate children to adoptive parents as if in a 'normal' parentchild biology (cf. Weismantel 1995; Schrauwers 1999) ${ }^{16}$ nor the fictive kinship Stack (1974) described for poor African-Americans. Nor is it the putative kinship of clientage in a unilineal segmentary kinship system where poor individuals and groups are taken into a wealthy unilineal kin group and subsumed, genealogically, within it. ${ }^{17}$ Equally, it is not the kinship of common ingestion that Carsten (1995) describes for Malays in Pulau Langkawi.

True, Stack's notion of fictive kinship, Weismantel's and Schrauwers' of adoptive kinship and Carsten's of kinship through commonality of food intake are instructive, since all are concerned with kinship built upon relationships of reciprocity, materiality and contingent social networks rather than readily traceable genealogies. The people whose lives Stack described used kin terms to reflect the closeness or otherwise of their material reciprocal relationships. Adults who supported a child could claim the right to be regarded as its parent. Two women who helped each other regularly over the long term regarded themselves as sisters. Individuals who reneged on expected material obligations to genealogically close kin lost the right to describe their relationships in kin terms. The same is true for the people of Khayelitsha.

Absent from Stack's notion of fictive kinship and from Weismantel's of adoptive kinship, however, is any reference to a sedimented cultural structure such as that which clanship offered Khayelitsha residents as a basis for creating genealogies and underpinning social networks. Neither author offers evidence that the

South Africa's Gini coefficient for 2006 was 0.72 , for 2011 it was 0.65 and for 2015 it was 0.68 (Statistics South Africa 2014; see also 'Poverty trends in South Africa: an examination of absolute poverty between 2006 \& 2015', Statistics South Africa media release, 22 August $2017<$ http:/l www.statssa.gov.za/? $p=10341>$, accessed 18 January 2018). According to the World Bank's index mundi, South Africa's inequality index is globally the highest $(<$ https://www.indexmundi. com/facts/indicators/SI.POV.GINI/rankings>, accessed 18 January 2018).

${ }^{15}$ W. Gumede, 'Ethnic nationalism: Zuma's style of divisive politics', Business Day, 19 October 2016 <https://www.businesslive.co.za/bd/opinion/2016-10-19-ethnic-nationalism-zumas-style-of/>; M. Mkhabela, 'Is Ramaphosa the ethnic unifier the ANC needs?', News24, 8 December 2017 $<$ https://www.news24.com/Columnists/Mpumelelo_Mkhabela/is-ramaphosa-the-ethnic-unifier-theanc-needs-20171208>, both accessed 8 December 2017. See also Mamdani (1996: especially 187-9).

${ }^{16}$ Weismantel (1995) describes adoptive kinship among Zumbaguans in Ecuador, and Schrauwers (1999) among To Pamona of Sulawi, Indonesia.

${ }^{17}$ The $u k u k h o n z a$ practice among precolonial Nguni people is an example where a wealthy and powerful man affiliated poor people as servants to his homestead and ultimately to his lineage, and where, after some generations, they became full (albeit junior) lineage members (see also Ferguson 2015: 144-6). 
kinship constructed in their respective research areas was built on culturally embedded ideas about kinship. The fictive kinship Stack describes appears to be based exclusively on material and sometimes emotional reciprocities, and constructed purely in the contingent application of kinship terminology. The adoptive kinship Weismantel describes seems to be similarly built on material reciprocities with a patina of emotionality, although she does stress the symbolic significance of the specific materials exchanged (food in particular).

By contrast, the kinship of common ingestion that Carsten describes along with her stress on the symbolic significance for emic definitions of kinship, of the house, and of food preparation and food consumption (rather than simply on material exchanges) make her argument resonate strongly with mine. Schrauwers' argument does too when he refers to a To Panoma "moral injunction of official kinship - "it is forbidden [for kin] to calculate costs and benefits" (1999: 312).

Neither makes reference to ideas about clanship and genealogy. Yet both reveal a cultural structure underlying people's constructions of kinship links - an enduring yet historically and contingently changing cultural structure of a kind similar to that which White (2010: 508) describes as pertaining to the relationship between homestead layout, kinship and commemoration of the ancestors in post-apartheid rural Zululand. In the case of the cultural structure of kinship being drawn upon by early 1990s Khayelitsha residents, it is a structure that Bourdieu (1977: 33ff.) calls 'official kinship', which, he says, is recursively and dialectically related to 'practical kinship', the transacted construction of kinship links, relationships and genealogies (cf. Cohen and Comaroff 1976).

'Putative' reciprocity-based kinship relationships and networks found in Cape Town's Khayelitsha population are not constructed on kinship terminologies alone. Nor are they constructed around the particularities of the materials exchanged. They are built around a shared understanding that kinship is indeed a complex of genealogy, not just terminology or materiality.

To describe someone as kin, and to call upon that person to behave with the morality befitting a kinsperson, one must construct a genealogy by using clan names and activating the latent kin links they generate. Without clanship at its base, everyone knows it is really just a fictive relationship. Links of common clanship, and links established through tracing affinal links between clans, are thus understood to have particular efficacy for reinforcing the interpersonal bonds at the core of social networks, bonds people create and use to face the vagaries of urban township life.

Kinship here is not a principle for constructing long-lasting corporate groups. It is, however, a crucial defining feature of relatedness as used for the construction and manipulation of social networks that has long characterized life for poor Africans in contemporary South Africa and continues to do so. It is a keen cultural resource, sustained by people's efforts to define their relationships, giving them meaning by reference to genealogies and clan-based linkages. It is a popular ideational resource that simultaneously appeals to idioms of biology and genealogy and immediately undermines them in any material sense. It is also constantly in the process of being transformed, precisely through being called upon and used.

Understanding kinship in this way has a threefold value. It confirms, once again, the paucity of positivist notions underlying perceptions of kinship as a purely observable and recordable structure based on biology. It demonstrates that there 
is, nonetheless, a universal process whereby people attempt to construct a sense of relatedness using various referents for culturally constructing notions of identity by drawing on familiar idioms and ideas that resonate with past experience, and yet change as they are drawn upon. It thus illustrates the structuredness of popular ideas about relationships, and the processes through which, as cultural structures, those ideas are transformed each time they are used in the pragmatics of everyday life. As people create and reinforce social networks around their use of kinship links, they also reformulate their ideas about what constitutes kinship. The culture of kinship is thus reinvented over and over again, each time emerging anew.

\section{Acknowledgements}

I am indebted to Anthony Mongameli Mehlwana who generated most of the empirical material on which this article is based (cf. Mehlwana 1996; Spiegel and Mehlwana 1997). I acknowledge support from the now defunct (South African) Human Sciences Research Council's Cooperative Programme on Marriage and Family Life and the Wenner-Gren Foundation. I am also grateful to Katja Werthmann and the other participants in the 2015 Urban Kinship Writeshop, to the two generous readers of the article and especially to Fiona Ross and Hylton White.

\section{References}

Bähre, E. (2007) 'Reluctant solidarity: death, urban poverty and neighbourly assistance in South Africa', Ethnography 8 (1): 33-59.

Berry, S. (1993) No Condition is Permanent. Madison WI: University of Wisconsin Press.

Bloch, M. (1971) 'The moral and tactical meaning of kinship terms', Man 6 (1): 79-87.

Bourdieu, P. (1977) Outline of a Theory of Practice. Cambridge: Cambridge University Press.

Carsten, J. (1995) 'The substance of kinship and the heat of the hearth: feeding, personhood and relatedness among Malays in Pulau Langkawi', American Ethnologist 22 (2): 223-41.

Casale, D. and D. Posel (2006) 'Migration and remittances in South Africa: background document on migration and first set of draft questions for inclusion in the National Income Dynamics Study'. Unpublished paper, Durban and Cape Town.

Cohen, A. and J. Comaroff (1976) 'The management of meaning: a phenomenology of political transactions' in B. Kapferer (ed.), Transaction and Meaning. Philadelphia PA: Institute of the Study of Human Issues.

Cole, J. (1987) Crossroads: the politics of reform and repression. Johannesburg: Ravan Press.

Comaroff, J. and J. L. Comaroff (1981) 'The management of marriage in a Tswana chiefdom' in J. L. Comaroff and E. Krige (eds), Essays in African Marriage in Southern Africa. Cape Town: Juta. 
Cunnison, I. (1957) 'History of genealogies in a conquest state', American Anthropologist 59 (1): 20-31.

Cunnison, I. (1959) The Luapula People of Northern Rhodesia: custom and history in tribal politics. Manchester: Manchester University Press for the RhodesLivingstone Institute.

du Toit, A. and D. Neves (2007) 'In search of South Africa's "second economy": chronic poverty, economic marginalisation and adverse incorporation in $\mathrm{Mt}$ Frere and Khayelitsha'. CPRC Working Paper 102. Bellville: Programme for Land and Agrarian Studies, University of the Western Cape.

Feldman-Savelsberg, P. (1995) 'Cooking inside: kinship and gender in Bangangté idioms of marriage and procreation', American Ethnologist 22 (3): 483-501.

Ferguson, J. (1990a) The Anti-Politics Machine: 'development', depoliticization and bureaucratic state power in Lesotho. Cambridge: Cambridge University Press.

Ferguson, J. (1990b) 'Mobile workers, modernist narratives: a critique of the historiography of transition on the Zambian Copperbelt', Journal of Southern African Studies 16 (3-4): 385-412, 603-21.

Ferguson, J. (2015) Give a Man a Fish: reflections on the new politics of distribution. Durham NC and London: Duke University Press.

Goody, J. (ed.) (1958) The Developmental Cycle of Domestic Groups. Cambridge: Cambridge University Press.

Grieco, M. M. (1995) 'Transported lives: urban social networks and labour circulation' in A. Rogers and S. Vertovec (eds), The Urban Context: ethnicity, social networks and situational analysis. Oxford and Washington DC: Berg Publishers.

Hammond-Tooke, W. D. (1985a) 'Descent groups, chiefdoms and South African historiography', Journal of Southern African Studies 11 (2): 305-19.

Hammond-Tooke, W. D. (1985b) 'Who worships whom: agnates and ancestors among the Nguni', African Studies 44 (1): 47-64.

Hammond-Tooke, W. D. (1991) 'Kinship authority and political authority in precolonial South Africa' in A. D. Spiegel and P. A. McAllister (eds), Tradition and Transition in Southern Africa. Johannesburg: Witwatersrand University Press.

Harper, S. and J. Seekings (2010) 'Claims on and obligations to kin in Cape Town, South Africa'. CSSR Working Paper 272. Cape Town: Centre for Social Science Research (CSSR), University of Cape Town.

Henderson, P. (1999) 'Living with fragility: children in New Crossroads'. PhD thesis, University of Cape Town.

Henderson, P. (2011) AIDS, Intimacy and Care in Rural KwaZulu-Natal: a kinship of bones. Amsterdam: Amsterdam University Press.

Holy, L. (1996) Anthropological Perspectives on Kinship. London: Pluto Press.

Hunter, M. (1936) Reaction to Conquest: effects of contact with Europeans on the Pondo of South Africa. London: Oxford University Press for the International African Institute.

James, D. (2012) 'Money-go-round: personal economies of wealth, aspiration and indebtedness', Africa 82 (1): 20-40.

Jones, S. (1993) Assaulting Childhood: children's experiences of migrancy and hostel life in South Africa. Johannesburg: Witwatersrand University Press.

Kotzé, J. C. (1993) In Their Shoes. Johannesburg: Juta. 
Krige, D. (2011) 'Power, identity and agency at work in the popular economies of Soweto and black Johannesburg'. PhD thesis, University of the Witwatersrand, Johannesburg.

Launay, R. (2006) 'Practical joking', Cahiers d'Études Africaines 46 (184): 795-808.

Mabin, A. (1990) 'Limits of urban transition models in understanding South African urbanisation', Development Southern Africa 7 (3): 311-22.

Mamdani, M. (1996) Citizen and Subject: contemporary Africa and the legacy of late colonialism. Cape Town: David Philip.

Manona, C. W. (1991) 'Relying on kin: ex-farm workers' adaptation to life in Grahamstown' in A. D. Spiegel and P. A. McAllister (eds), Tradition and Transition in Southern Africa. Johannesburg: Witwatersrand University Press.

McAllister, P. (2001) Building the Homestead: agriculture, labour and beer in South Africa's Transkei. Research Series 16. Leiden: African Studies Centre.

Mehlwana, A. M. (1996) 'The dynamics of cultural continuities: clanship in the Western Cape'. MA dissertation, University of Cape Town.

Meintjes, H., K. Hall, D.-H. Marera and A. Boulle (2010) 'Orphans of the AIDS epidemic? The extent, nature and circumstances of child-headed households in South Africa', AIDS Care: Psychological and Socio-medical Aspects of AIDS/HIV 22 (1): 40-9.

Morgan, L. H. (1870) Systems of Consanguinity and Affinity of the Human Family. Washington DC: Smithsonian.

Murray, C. (1981) Families Divided: the impact of migrant labour in Lesotho. Cambridge: Cambridge University Press.

Murray Li, T. (1998) 'Working separately but eating together: personhood, property and power in conjugal relations', American Ethnologist 25 (4): 675-94.

Oliver-Evans, C. (1993) 'Employment and urbanisation: the impact of the abolition of influx control in the Western Cape'. SALDRU Working Paper 84. Cape Town: Southern Africa Labour and Development Research Unit (SALDRU), University of Cape Town.

Posel, D. (2004) 'Have migration patterns in post-apartheid South Africa changed?', Journal of Interdisciplinary Economics 15 (3-4): 277-92.

Preston-Whyte, E. (1974) 'Kinship and marriage' in W. D. Hammond-Tooke (ed.), The Bantu Speaking Peoples of Southern Africa. London: Routledge and Kegan Paul.

Ramphele, M. (1993) A Bed Called Home. Cape Town: David Philip.

Reynolds, P. F. (1989) Childhood in Crossroads. Cape Town: David Philip.

Reynolds, P. F. (1993) 'Paring down the family: the child's point of view' in D. R. Braude (ed.), Children and Families in Distress: working papers from a seminar held on 25-26 July 1991. HG/MF-9. Pretoria: HSRC Co-operative Research Programme on Marriage and Family Life.

Robins, S. (2014) 'The 2011 toilet wars in South Africa: justice and transition between the exceptional and the everyday after apartheid', Development and Change 45 (3): 479-501.

Ross, F. C. (1990) 'Strategies against patriarchy: women and rotating credit associations'. Unpublished BA (Honours) essay, University of Cape Town.

Ross, F. C. (1995) Houses without Doors: diffusing domesticity in Die Bos. HG/MF-25. Pretoria: HSRC Co-operative Research Programme on Marriage and Family Life. 
Ross, F. C. (1996) 'Diffusing domesticity: domestic fluidity in Die Bos', Social Dynamics 22 (1): 55-71.

Russell, M. (2003) 'Understanding black households: the problem', Social Dynamics 29 (2): 5-47.

Saltzman, A. B. (2013) 'Mobile patients, static response: (mis)managing wellbeing amidst South Africa's dual epidemic'. PhD thesis, Harvard University.

Schneider, D. (1984) A Critique of the Study of Kinship. Ann Arbor MI: University of Michigan Press.

Schrauwers, A. (1999) 'Negotiating parenthood: the political economy of "kinship" in Central Sulawesi, Sumatra', American Ethnologist 26 (2): 310-23.

Seekings, J. (2008) 'Beyond "fluidity": kinship and households as social projects', CSSR Working Paper 237. Cape Town: Centre for Social Science Research (CSSR), University of Cape Town.

Sharp, J. (1987) 'Relocation, labour migration and the domestic predicament: Qwaqwa in the 1980s' in J. Eades (ed.), Migrants, Workers, and the Social Order. London and New York NY: Tavistock.

Sharp, J. and A. D. Spiegel (1985) 'Vulnerability to impoverishment in South African rural areas: the erosion of kinship and neighbourhood as social resources', Africa 55 (2): 133-52.

Shaw, M. K. (2017) 'The familial and the familiar: locating relatedness in Colombian donor conception', Medical Anthropology, pp. 1-14 (published online).

Siyongwana, P. Q. (2004) 'Informal moneylenders in the Limpopo, Gauteng and Eastern Cape provinces of South Africa', Development Southern Africa 21 (5): 851-66.

Smith, J. and I. Wallerstein (eds) (1992) Creating and Transforming Households. Cambridge: Cambridge University Press.

Spiegel, A. D. (1986) 'The fluidity of household composition in Matatiele, Transkei: a methodological problem', African Studies 45 (1): 17-35.

Spiegel, A. D. (1987) 'Dispersing dependants: a response to the exigencies of labour migration in rural Transkei' in J. Eades (ed.), Migrants, Workers, and the Social Order. London and New York NY: Tavistock.

Spiegel, A. D. and A. M. Mehlwana (1997) Family as Social Network: kinship and sporadic migrancy in the Western Cape's Khayelitsha. HG/MF-31. Pretoria: HSRC Co-operative Research Programme on Marriage and Family Life.

Spiegel, A., V. Watson and P. Wilkinson (1996a) 'Devaluing diversity? National housing policy and African household dynamics in Cape Town', Urban Forum 6 (1): 1-30.

Spiegel, A., V. Watson and P. Wilkinson (1996b) 'Domestic diversity and fluidity in some African households in Greater Cape Town', Social Dynamics 22 (1): 7-30.

Stack, C. (1974) All Our Kin. New York NY: Harper and Row.

Statistics South Africa (2014) Poverty Trends in South Africa: an examination of absolute poverty between 2006 and 2011. Report 03-10-06. Pretoria: Statistics South Africa.

Strathern, A. (1973) 'Kinship, descent and locality: some New Guinea examples' in J. Goody (ed.), The Character of Kinship. Cambridge: Cambridge University Press.

Strathern, M. (1992a) After Nature: English kinship in the late twentieth century. Cambridge: Cambridge University Press. 
Strathern, M. (1992b) Reproducing the Future: essays on anthropology, kinship and the new reproductive technologies. New York NY: Routledge.

Van der Waal, C. S. (1996) 'Rural children and residential instability in Gazankulu', Social Dynamics 22 (1): 31-54.

Watson, J. B. (1964) 'Anthropology in the New Guinea Highlands', American Anthropologist 66 (4): 1-19.

Weismantel, M. (1995) 'Making kin: kinship theory and Zumbagau adoptions', American Ethnologist 22 (4): 685-703.

Wells, J. (1993) We Now Demand: the history of women's resistance to pass laws in South Africa. Johannesburg: Witwatersrand University Press.

White, H. (2002) 'Tempora et mores: family values and the possessions of a postapartheid countryside', Journal of Religion in Africa 31 (4): 457-79.

White, H. (2010) 'Outside the dwelling of culture: estrangement and difference in postcolonial Zululand', Anthropological Quarterly 83 (3): 497-518.

White, H. (2013) 'Spirit and society: in defence of a critical anthropology of religious life', Anthropology Southern Africa 36 (3-4): 139-45.

Wilson, M. (1951) Good Company: a study of Nyakyusa age villages. London: Oxford University Press.

Wilson, M. (1969) 'The Nguni' in M. Wilson and L. Thompson (eds), Oxford History of Southern Africa. Vol. I. London: Oxford University Press.

Wilson, M. and A. Mafeje (1963) Langa: a study of social groups in an African township. Cape Town: Oxford University Press.

\begin{abstract}
One product of the vicissitudes of apartheid-era labour migration, of persistent constraints on urban settlement and of continuing post-apartheid oscillating migration between South Africa's cities and countryside has been extensive domestic fluidity for many South African working people. As a consequence, they have repeatedly created new social networks across the urban-rural social field. In making sense of those networks by reconfiguring their notions of kinship and clanship, they have demonstrated the significance of kinship as an identity idiom. Based on research in Cape Town's largest African township during the early 1990s period of transition from apartheid, the article shows how, through people's use of notions of clanship, they have recursively reconstructed their idiom of kinship in a context of systemic instability. This article uses ethnographic data from that time and context to argue that we need to understand kinship as a cultural resource, pragmatically used and reinvented over and over again, each time emerging anew. In doing so, the article shows that kinship is not a fixed, recordable structure and that, like so many aspects of culture, it is repeatedly reinvented and reconstituted in order to address pragmatic circumstances.
\end{abstract}

\title{
Résumé
}

Pour beaucoup de travailleurs sud-africains, l'un des produits des vicissitudes de la migration de main-d'œuvre sous l'apartheid, des contraintes persistantes sur l'implantation urbaine et de la migration oscillante continue post-apartheid entre les villes et la campagne sud-africaines, a été une importante fluidité domestique. En conséquence, ces travailleurs ont créé de nouveaux réseaux sociaux de façon répétée dans le champ social ruro-urbain. En donnant du sens à ces réseaux en 
reconfigurant leurs notions de parenté et d'appartenance au clan, ils ont démontré l'importance de la parenté comme idiome d'identité. Basé sur des recherches menées dans le plus grand township africain de Cape Town au cours de la période de transition de l'apartheid au début des années 90, l'article montre comment, à travers l'usage de notions d'appartenance au clan, les gens ont reconstruit par récurrence leur idiome de parenté dans un contexte d'instabilité systémique. L'article utilise des données ethnographiques de cette période et de ce contexte pour soutenir qu'il faut comprendre la parenté comme une ressource culturelle utilisée de manière pragmatique et sans cesse réinventée, émergeant chaque fois nouvelle. Ce faisant, l'article montre que la parenté n'est pas une structure fixe enregistrable et que, comme tant d'aspects de la culture, elle est réinventée et reconstituée de manière récurrente pour pallier des circonstances pragmatiques. 